in relation to other public events remembered and dismembered through a network of often incompatible narratives. Indeed, James's demonstration of the protean flexibility of the Gunpowder Plot as a premise for later seventeenthcentury anti-terrorist narratives of all stripes-anti-Catholic, -puritan, -Laudian, -Spanish, -Irish; anti-monarchist and anti-anti-monarchist-offers a salutary warning against our own tendency to narrate our age as "post-9/11": always-already inflected by a supposedly, yet debatably, singular event and the endless episodes of the War on Terror since framed and reframed by it.

LEAH KNIGHT

Brock University

Kahn, Didier, ed.

\title{
La Messe Alchimique attribuée à Melchior de Sibiu.
}

Textes de la Renaissance 197, Série Alchmie 1. Paris: Classiques Garnier, 2015. Pp. 149. ISBN 978-2-8124-3274-3 (paperback) €29.

This small volume by Didier Kahn is the first in a new series by Classiques Garnier dedicated to alchemy that is also coincidentally directed by the author. La Messe alchimique has long been considered by most scholars in the field as an object of curiosity resisting clear genre categorization and not exactly worthy of serious scholarly consideration-like many other alchemical texts dating from the end of the sixteenth and beginning of the seventeenth centuries.

With this offering, Kahn's goal is twofold. First, he clearly aims at giving legitimacy to a unique text that has long been relegated to the margins of the textual canon: thus, the impressive editorial apparatus displayed for a text of only five pages in its Latin version, and four pages in its French translation. Second, Kahn explicitly states that he wishes to use La Messe alchimique as a pretext to formulate a historical synthesis of the relationship between alchemy and religion based on the study of textual sources taken from both religious and alchemical literatures from the Middle Ages to the seventeenth century. With the very first words of his edition, Kahn rightfully warns his readers about the problematic relationship between alchemy and religion, and the too often automatic categorization of texts linked to the alchemical discipline as heresy. Kahn suggests that La Messe alchimique, in spite of the potentially controversial 
content expressed by its title, paradoxically constitutes a prime example of a text wrongly considered unorthodox by many readers, although its diffusion through the years was permitted by the interest it triggered with readers of the most various and contradictory religious affiliations.

As an introduction, Kahn gives a brief and informative history of the relationship between alchemy and religion through the Middle Ages. A major distinction between the conception of alchemy during the Middle Ages and the Renaissance is that the medieval conception of the alchemical arts was strictly exoteric, that is to say, primarily concerned with the transmutation of base metals into precious ones, and with the prolongation of human life by an elixir vitae. Sometimes both of these goals were simultaneously considered in the elaboration of a "universal medicine" to the service of both beings and metals. The link between alchemy and religion during the Middle Ages was of three possible orders: the alchemical interpretation of sacred texts, among which the most common is the analogy between the passion of Christ and the quest of the philosopher's stone; the conception of alchemy as an activity partly divine in nature; and the inscription of the alchemical arts into eschatological considerations. According to Kahn, only during the Renaissance can we notice the emergence of the notion of esoteric or spiritual alchemy, designating an interior transmutation of the practitioner of the alchemical procedure. Kahn insists on the almost natural relationship between the exegetic activity and the alchemical quest during the Middle Ages-creating the context favourable to the exploitation of a liturgical textual form in the expression of alchemical knowledge by a mid-fifteenth-century alchemist of Central Europe who gave us La Messe alchimique.

Kahn begins the edition of La Messe alchimique with a presentation of the text going through the many manuscripts, the earliest one dating from 1580, and printed editions, of which the earliest one dates from 1597 and is attributed to a Calvinist militant named Nicolas Barnaud. Naturally, the great majority of these texts are in Latin, but Kahn also uses Czech and German manuscript translations for the establishment of his edition. Surprisingly, there is no source document of the text dating from the medieval period; the provenance and the attribution of La Messe alchimique are entirely based on paratextual elements found mostly in a Latin manuscript kept in Vienna dating from the beginning of the seventeenth century. With the help of fewer than a dozen versions of the text, and by reconsidering the abundant existing scholarship on the question, 
Kahn is able to establish the origin of the text as being the court of Ladislaus the Posthumous in Prague or Vienna in the middle of the fifteenth century $(1440-57)$. As for the supposed author of the text, the obscure Melchior of Sibiu, Kahn can only suggest that his name, kept by tradition, is probably the fruit of a misreading, and that the work was probably written by a priest, named Nicolas, attached to the court of the king of Hungary, Croatia, and Bohemia.

Unexpectedly, according to Kahn, the text is entirely orthodox on a liturgical perspective but appears to display a logic more in tune with alchemical imperatives. On the question of the interpretation of the text, Kahn does not hesitate to disclose his communications with the various experts he consulted in the elaboration of his edition, often quoting from casual correspondence in both the footnotes and the main text. The tone of these quotes can be unsettling at first, but they help give a more accessible perspective to a theological expertise that could be quite dry for most readers. The same can be said for the alchemical reading of the Mass, where Kahn's expertise becomes obvious but always remains accessible to his readers, who could be approaching the text from the various perspectives of history, theology, or literature.

The final and most fascinating part of the edition concerns the transmission and reception of La Messe alchimique. Kahn diligently illustrates all the variations resulting from the different editions of the text, trying to find motivations for these changes in the religious affiliations of the various editors through time. Closely observing the editions and the comments on the text by Catholics, Calvinists, Jesuits, Lutherans, and Paracelsians, Khan comes to the conclusion that the interest generated by La Messe alchimique was essentially alchemical in nature, underlining the fundamentally transconfessional character of the discipline.

Kahn succeeds in demonstrating that La Messe alchimique is decidedly a text worthy of interest, if not for its content, most certainly for the context of its creation and reception. The author's vast erudition and insight found in this first volume decidedly put this collection, exclusively dedicated to alchemical texts, on the right path.

PHILIPPE BAILLARGEON

University of Massachusetts, Amherst 